\title{
Tuberous sclerosis complex: from basic science to clinical phenotypes
}

John B.P. Stephenson

Fraser of Allander Neurosciences Unit, Royal Hospital For Sick Children, Glasgow Scotland, U.K.

Tuberous sclerosis complex: from basic science to clinical phenotypes, edited by Paolo Curatolo. International Review of Child Neurology Series: published in 2003 by Mac Keith Press and Cambridge University Press, London UK, ISBN: 1-898-68339-5, 314 pages, $£ 55$ or $\$ 75$.

This is an excellent book devoted to the tuberous sclerosis complex (TSC), edited by the president of ICNA (the International Child Neurology Association). Those of you who are ICNA members will already have received a copy from Mac Keith Press and doubtless formed your own good opinions (and those of you who are not ICNA members should join at the most favourable rate available for your country's economic situation!). Tuberous sclerosis (or TSC as it is now called) is one of the most common conditions to come to the attention of the pediatric neurologist. The editor's aim is to "consolidate what is known about TSC in a single source, making it easier to apply this new information to the cure of individual patients, and perhaps stimulating scientific research on some of remaining questions about this devastating disease." He and 20 co-authors do this well in 17 chapters, 8 of which he has co-written himself.

I admit a personal interest in this condition. About 30 years ago I saw a baby girl with delayed and deviant development who had epileptic seizures in my presence. The seizures combined focal elements and runs of serial spasms. With difficulty one could detect here and there on her pale Scottish skin even paler macules, fancifully in the shape of

Correspondence: Prof. John B.P. Stephenson,

Fraser of Allander Neurosciences Unit

Royal Hospital for Sick Children

Yorkhill

Glasgow G3 8SJ

Scotland

U.K.

E-mail: john@jbpstephenson.com

Received: January 29, 2004.

Accepted: March 04, 2004. leaf an ash-tree leaf. Her mother wore thick makeup and was mortified when I asked her if she would wash her face thoroughly so that I could examine it. It was no surprise to see the angiofibromata (previously called adenoma sebaceum) on her cheeks. It was a surprise, though, to see so many calcified tubers on the lateral skull X-ray of this highly intelligent woman (computerized tomography scans had not yet arrived, far less magnetic resonance imaging!). Not long after this we published on white hair patches as the first sign of TSC (McWilliam RC, Stephenson JBP. Depigmented hair. The earliest sign of tuberous sclerosis. Arch Dis Child. 1978 Dec;53(12):961-3), a reference curiously overlooked in the chapter on dermatological manifestations. I also remember how my first multi-generation TSC family emerged. I was seeing a boy with "absences" and I asked him to hyperventilate, well to breathe deeply. He had short dark grey trousers and long school socks revealing knees with large white blotches. Immediately his mother was diagnosed and soon after her father. This was one of the families whose analysis led first to an ABO linkage and then to the localization of the first gene (later TSC1) onto chromosome 9, and hence to the marvellous molecular genetics story as told by Julian Sampson and others in chapter 14 .

Forgive the tedium but perhaps the excitement of a list of the contents of the book: preface by Harvey Sarnat, editor's preface, historical background, diagnostic criteria, neurological manifestations, seizures, intellectual and cognitive impairments, autism, neuroimaging, positron emission tomography, dermatological and stomatological manifestations, ophthalmological manifestations, renal involvement, cardiac and vascular involvement, hepatic lung splenic and pancreatic involvement, molecular genetics, neuropathology, molecular neurobiology and future directions. Several of these excellent chapters illustrate the eternal paradox of pediatric neurology: the excitements of clinical diagnosis and scientific discovery and the agony of impairments disability and handicap often compounded by the difficulty of explaining to parents that their beautiful baby is irrevocably 
damaged.

Isaac Newton-though he was not of course the first to say this-wrote that he could see further because he was standing on the shoulders of giants. The previous giant of tuberous sclerosis was
Manuel Gomez of the Mayo Clinic. The present giant is surely Paolo Curatolo. Others will surely stand on his shoulders, some of whom may have their enthusiasm first lit by reading this book. Pediatric neurologists, make sure you have it! 